Newfoundland and Labrador Studies

\title{
Kathleen Winter. Lost in September
}

\section{Laura M. Robinson}

Volume 33, numéro 2, 2018

URI : https://id.erudit.org/iderudit/1058085ar

DOI : https://doi.org/10.7202/1058085ar

Aller au sommaire du numéro

\section{Éditeur(s)}

Faculty of Arts, Memorial University

ISSN

1719-1726 (imprimé)

1715-1430 (numérique)

Découvrir la revue

Citer ce compte rendu

Robinson, L. (2018). Compte rendu de [Kathleen Winter. Lost in September]. Newfoundland and Labrador Studies, 33(2). https://doi.org/10.7202/1058085ar d'utilisation que vous pouvez consulter en ligne.

https://apropos.erudit.org/fr/usagers/politique-dutilisation/ 
Kathleen Winter. Lost in September. Toronto: Alfred A. Knopf Canada, 2017. ISBN 978-0-345-81012-0

Kathleen Winter's debut novel Annabel, about a gender fluid young person coming of age in Labrador and St. John's, met with widespread critical acclaim and my own personal admiration, so I was very keen to pick up her next fictional offering, Lost in September. While sharing a focus with its predecessor on the fluidity or ambiguity of identity, Lost is quite a departure from the earlier novel. Winter tells the story of a young man in Quebec in September 2017 who believes himself to be General James Wolfe, the historical figure who fought against Montcalm on the Plains of Abraham. The central premise is Jimmy's attempt to regain the lost time when Wolfe was to be on leave, but the calendars changed that year from the Julian to the Gregorian, thus eliminating 11 days of September and consequently Wolfe's leave. It is a compelling premise, demonstrating both the constructedness of time, which we often take for an invariable fact, and the mutability of identity. Winter crafts a modern-day/historical quest narrative, in that the young present-day Wolfe meanders through first Montreal and then Quebec City, encountering various tragic or quite literally colourful individuals who guide him on his journey. In addition to the homeless Sophie, with whom he shares a tent on Mont Royal, Jimmy meets historian Genevieve Waugh, who is researching for a book on James Wolfe and who is struck by the young man's similarity to the historical figure.

Winter organizes the novel into four sections that name characters who affect Jimmy's quest. The Yellow Man proves to be a blind man who can then inexplicably see, whose golden multi-purpose service dog, Veronica, might well be the redemptive part of the novel. The Blue Man emerges in a story that Jimmy tells of his, James Wolfe's, past; this figure explains that "you have to go back in time, not just forward" (164), which provides some shape for the time travel that appears to be happening. The Red Man is, of course, Jimmy, in his 
English general's coat and with his red hair. The Green Man is a traditional figure of protection James Wolfe encountered in Scotland when he fought with the English to suppress the Scottish; ironically, the Green Man would have been evoked to protect the Scottish from the English. Jimmy sees himself clearly as having done ill even if he emerged as the victor. He needs protection from himself.

The quest motif - and we're not entirely sure what Jimmy is looking for: his identity? the lost days? escape? — is told largely in a riff on an epistolary style, a genre quite popular in Wolfe's time, the mid-1750s. The novel opens and closes with letters and much of the narrative emerges through letters exchanged or letters that Jimmy writes in his head. This style foregrounds the individual as it necessarily employs the first person, as does the internal monologue of the rest of the novel, placing the reader in the mind of the characters. What Jimmy or James Wolfe is questing for is a truth grounded in the past about his identity, a truth beyond a straightforward historical narrative often verified through letters. Winter also creates a metafictional element as letters by Genevieve Waugh, the researcher hard at work on a book about Wolfe, open and close the novel. Jimmy says to her, "you are writing a book about me, are you not?" (18). Indeed, the reader becomes aware that the book she is holding must bear some resemblance to the one that Genevieve has completed.

That book, both the one the reader holds and the one that Genevieve has written, is about the trauma of soldiers, about the scarring of battle and the recurring guilt over decisions made and paths taken. General Wolfe set fire to communities and had his soldiers kill families. While the military narrative creates and expresses trauma, it also offers an escape from trauma, as Lost in September tells, in part, the story of socially unacceptable gay desire that life in the military enables. Hanging over both present-day Jimmy's story and Wolfe's recounting of his life is the cloud of post-traumatic stress disorder. Jimmy joins up with several rather colourful mentally ill individuals on his journey to healing. This individual battle plays out on a palimpsest of the larger 
political battle, often quite literal, between the English and the French, the maudits anglais and the Québécois.

I don't want to reveal key pieces of the narrative that unravel slowly, so I can't provide much more information about the storyline. I did find this novel deeply frustrating to read, even while I found it lovely and lyrical. I am citing at length an example of Winter's gorgeous language describing Jimmy's recollection of Hotteterre's Prelude; not only lyrical, this passage also seems to represent the movement of the novel itself:

I can hear every note of its tender fallibility, its spaces, its unassuming shape. It meanders like a small country stream of no importance to anyone but young walkers, longlegged spiders, dragonflies and slender ducks. Its emotion is an innocent happiness, though not a witless flight of childish primary colour - it remembers all the clear-eyed queries I made as a serious child, of the rivers and fields. It suggests botanical exactitude, painterly adherence to precise ochres, chlorophylls and butterfly dyes. The prelude travels - I ride it now - takes modest flight, alights on an ear of wild grass, stays in one place and listens. It paces itself then runs ahead, serious and merry yet never frivolous, weightless yet not sweet. Its rhythms are contained as time contains a line that has no end. (27)

The frustration I experienced reading Lost was because I too felt lost reading it, which might just have been the point. I could not suspend my disbelief - Jimmy cannot really be General Wolfe, can he? — and I was bothered that characters in the novel seemed to be able to do so. While I pride myself on a modicum of theoretical sophistication that embraces the fluidity of identity, perhaps I found my limits when reading this novel. However, Lost in September is also the kind of book that ages well. It haunted me after I closed the cover. General James Wolfe writes in a letter to the writer Genevieve Waugh, "All I want ... is for 
you to understand my plight, and perhaps, if you can, relay it to others" (26). Kathleen Winter's success in this novel is precisely that, for she leaves the reader as confused and as haunted as the distraught soldier in his attempt to adapt to ordinary life.

Laura M. Robinson

Grenfell Campus, Memorial University of Newfoundland 